\title{
Kataster jako warunek reformy systemu opodatkowania nieruchomości w Polsce
}

\section{Cadastre as a condition of the property tax system reforms in Poland}

\begin{abstract}
Streszczenie. Opodatkowanie majątku nieruchomego jest tradycyjnym elementem systemu podatkowego w wielu krajach. Podatki majątkowe stanowią tę grupę danin publicznych, która jest najbardziej zróżnicowana pod względem formy i konstrukcji. Brak międzynarodowych standardów, które wyznaczałyby zasady konstrukcji podatków majątkowych, nie istnieje również jeden powszechnie akceptowalny ich system. Od momentu rozpoczęcia w Polsce reform mających na celu dokonanie zasadniczych zmian ustrojowych i politycznych wskazuje się na potrzebę zreformowania obowiązującego w Polsce systemu opodatkowania nieruchomości. Proponuje się zmianę formuły opodatkowania z funkcjonującego obecnie opodatkowania powierzchni na opodatkowanie w formule ad valorem, czyli na opodatkowanie wartości nieruchomości.
\end{abstract}

Słowa kluczowe: system podatkowy; podatek od nieruchomości; podatek katastralny. 


\begin{abstract}
Real property taxation is a traditional element of the tax system in many countries. Property taxes constitute the group of public levies that is the most diversified in the form and construction. There are no international standards which would indicate the rules of constructing property taxes, no commonly acceptable system exists either. Since the reforms that aim at introducing basic political changes in Poland started, the need to reform the Polish system of the taxation of property has been indicated. A change of the tax formula from the area taxation to ad valorem taxation, i.e. property value tax is suggested.
\end{abstract}

Keywords: tax system; property tax; cadastral tax.

\title{
1. Wprowadzenie
}

Opodatkowanie majątku nieruchomego jest tradycyjnym elementem systemu podatkowego w większości krajów. Podatki majątkowe stanowią jednakże tę grupę danin publicznych, która jest najbardziej zróżnicowana pod względem formy i konstrukcji. W teorii i praktyce można wyróżnić dwa podstawowe modele opodatkowania nieruchomości. Pierwszy z nich, obowiązujący obecnie w Polsce, opiera się na powierzchni nieruchomości jako podstawie opodatkowania. Drugi, charakterystyczny dla krajów o wielowiekowych tradycjach poszanowania prawa własności, wysoko rozwiniętym i zidentyfikowanym pod względem podmiotowym, przedmiotowym i wartościowym systemie informacyjnym prowadzonym dla rynku nieruchomości, określany jest mianem katastru. W tym drugim przypadku jako podstawę opodatkowania wykorzystuje się wartość nieruchomości określoną w tym systemie.

Warto podkreślić, iż brak międzynarodowych standardów, które wyznaczałyby zasady konstrukcji podatków majątkowych, nie istnieje również jeden powszechnie akceptowalny ich system. Dlatego też, jak zauważa Leonard Etel, „system opodatkowania nieruchomości jest różnie rozumiany w zależności od kraju, w którym jest stosowany” ${ }^{\text {. Pro- }}$ blematyka opodatkowania nieruchomości nie jest przedmiotem regulacji

1 L. Etel (red.), Europejskie systemy opodatkowania nieruchomości, Warszawa 2003, s. 7; szerzej: L. Etel, Reforma opodatkowania nieruchomości w Polsce, Białystok 1998, s. 13 i n. 
prawa wspólnotowego ani nie jest objęta dyrektywami harmonizacyjnymi Unii Europejskiej.

Od momentu rozpoczęcia w Polsce reform mających na celu dokonanie zasadniczych zmian ustrojowych i politycznych wskazuje się na potrzebę zreformowania obowiązującego w Polsce systemu opodatkowania nieruchomości. Proponuje się zmianę formuły opodatkowania z funkcjonującego obecnie opodatkowania powierzchni na opodatkowanie w formule ad valorem, czyli opodatkowanie wartości nieruchomości. Przyjęta jako podstawa opodatkowania wartość nieruchomości ma nosić miano wartości katastralnej i wynikać będzie z zapisu określającego jej wysokość w katastrze nieruchomości. Szczególną jednak uwagę należy zwrócić na to, iż wartość katastralna nie ma być wartością czysto rynkową, a zostanie określona w procesie powszechnej taksacji nieruchomości wraz z uwzględnieniem różnic, jakie występują miedzy poszczególnymi nieruchomościami na terenie danej gminy, oraz zbliżeniem tej wartości do wartości rynkowej możliwej do uzyskania przy zastosowaniu metod przyjętych dla wyceny masowej.

Celem opracowania jest przedstawienie stanu obecnego, przesłanek reformy i proponowanych zmian w zakresie opodatkowania nieruchomości w Polsce.

\section{Pojęcie i obecny system opodatkowania nieruchomości}

Systemem opodatkowania nieruchomości określa się zbiór jednocześnie obowiązujących podatków, których przedmiotem jest władanie nieruchomością. Obowiązek zapłaty podatku wynika $\mathrm{z}$ faktu posiadania i użytkowania nieruchomości. Jest to jedyne kryterium zaliczenia danego podatku do systemu opodatkowania nieruchomości. Obecnie na system opodatkowania nieruchomości składają się trzy podatki, a mianowicie: podatek od nieruchomości, podatek rolny i podatek leśny. Najszerszy zakres przedmiotowy ma podatek od nieruchomości, albowiem obciąża grunty, budynki i budowle. Natomiast przedmiotem opodatkowania podatkiem rolnym lub leśnym są jedynie grunty. Wyłączenie grun- 
tów z opodatkowania podatkiem od nieruchomości wymaga spełnienia co najmniej dwóch warunków przewidzianych przez ustawodawcę:

1. muszą one być odpowiednio sklasyfikowane w ewidencji gruntów i budynków jako:

- użytki rolne;

- $\quad$ grunty zadrzewione i zakrzewione na użytkach rolnych;

- lasy;

2. nie mogą zostać zajęte na prowadzenie działalności gospodarczej innej niż działalność rolnicza lub leśna².

W przypadku gruntów można byłoby pokusić się o stwierdzenie, iż podatki te pozostają wobec siebie w swoistej konkurencji, gdyż w zależności od przeznaczenia nieruchomości na cele rolnicze, leśne czy też prowadzenia działalności gospodarczej dana nieruchomość może być objęta jednym z tych trzech podatków ${ }^{3}$.

Obowiązujący obecnie system opodatkowania nieruchomości powstał na zasadzie ciągłego dostosowywania jego elementów do zmieniających się warunków społeczno-gospodarczych. Jest typowym „systemem historycznym”, ukształtowanym stopniowo w drodze ciągłych zmian konstrukcji podatków go tworzących. Jego budowa nie była oparta na przyjętych z góry założeniach, ale na „bieżącym dostosowywaniu” poszczególnych podatków do istniejącej sytuacji społeczno-gospodarczej ${ }^{4}$. Dostosowywanie systemu przebiegało w określonych, systematycznie realizowanych kierunkach. Proces ten był szczególnie zauważalny w przypadku podatku od nieruchomości oraz podatku rolnego:

- stopniowo ujednolicano podatki dotyczące nieruchomości, co w rezultacie tworzyło grupy świadczeń, w których podstawą opodatkowania jest powierzchnia nieruchomości;

- $\quad$ konstrukcja poszczególnych podatków ulegała uproszczeniu;

- $\quad$ ulegały nowelizacjom istniejące regulacje prawne.

L. Etel, R. Dowgier, Podatki i opłaty lokalne - czas na zmiany, Białystok 2013, s. 20.

R. Mastalski, Prawo podatkowe II, część szczegółowa, Warszawa 1996, s. 229.

4 L. Etel, Opodatkowanie nieruchomości: problemy praktyczne, Białystok 2001, s. 27. 
Pierwowzorem obowiązującej aktualnie ustawy o podatku od nieruchomości ${ }^{5}$ jest wywodzący się z lat 50. ubiegłego wieku podatek, który wówczas uregulowany był w dekrecie o podatkach i opłatach terenowych $^{6}$. Konstrukcja tego podatku różniła się znacznie od aktualnie obowiązującej. Podstawą opodatkowania nieruchomości była wartość nieruchomości oszacowana według wartości czynszowej, obiegowej, amortyzacyjnej lub bilansowej, i dotyczyła ona jedynie opodatkowania budynków, natomiast po raz pierwszy pojawiła się tam jako podstawa opodatkowania gruntów powierzchnia wyrażona w metrach kwadratowych ${ }^{7}$.

Ustawa z dnia 19 grudnia 1975 r. o niektórych podatkach i opłatach terenowych ${ }^{8}$ zmieniała podstawę opodatkowania, którą od tej pory stała się powierzchnia. Stanowiła ona od tego czasu podstawę opodatkowania nie tylko gruntów, ale również budynków niewynajętych lub niewydzierżawionych, stanowiących własność osób fizycznych i prawnych, które nie były jednostkami gospodarki uspołecznionej. W przypadku gruntów wydzierżawionych w dalszym ciągu podstawę wymiaru podatku stanowił czynsz - z zastrzeżeniem, że obliczony podatek od czynszu nie mógł być niższy niż obliczony podatek od gruntów. W przypadku, gdy wartość podatku od czynszu była niższa, podstawą opodatkowania automatycznie stawała się powierzchnia gruntów. W budynkach położonych na terenie miast podstawą opodatkowania lokali stała się powierzchnia lokalu, a nie jak dotychczas - jego wartość.

W latach 80. ubiegłego wieku wprowadzono dwie odrębne ustawy regulujące opodatkowanie podatkiem od nieruchomości. Rozdzielały one opodatkowanie jednostek gospodarki uspołecznionej od jednostek gospodarki nieuspołecznionej i ludności. Ustawa z dnia 26 lutego 1982 r.

5 Ustawa z dnia 12 stycznia $1991 \mathrm{r}$. o podatkach i opłatach lokalnych (tekst jedn. Dz.U. z 2014 r., poz. 849).

$6 \quad$ Dekret z dnia 20 maja 1955 r. o podatkach i opłatach terenowych (tekst jedn. Dz.U. z 1963 r. Nr 16, poz. 87 ze zm.).

7 L. Etel, Opodatkowanie nieruchomości..., s. 28.

8 Ustawa z dnia 19 grudnia 1975 r. o niektórych podatkach i opłatach terenowych (Dz.U. Nr 45 poz. 229 ze zm.). 
o opodatkowaniu jednostek gospodarki uspołecznionej ${ }^{9}$ obejmowała swoim zakresem nie tylko opodatkowanie budynków i gruntów, ale i co było nowością - także opodatkowanie budowli. Podstawą opodatkowania gruntów pozostała powierzchnia, natomiast podstawę opodatkowania budynków i budowli stanowiła ich wartość amortyzacyjna.

Podatek od nieruchomości osób fizycznych i jednostek gospodarki nieuspołecznionej uregulowany został w ustawie z dnia 14 marca $1985 \mathrm{r}$. o podatkach i opłatach lokalnych ${ }^{10}$. Opodatkowaniu zgodnie z tą ustawą podlegały budynki lub ich części, grunty oraz - co było kolejną nowością - obiekty budowlane niezłączone trwale z gruntem. Jednocześnie ustawa znosiła podatek od lokali oraz zrezygnowano z wartości czynszowej jako podstawy opodatkowania.

Na mocy ustawy z dnia 28 grudnia 1989 r. o zmianie niektórych ustaw regulujących zasady opodatkowania połączono odrębne dotychczas podatki. Regulacja ta obowiązywała bardzo krótko i została zastąpiona aktualnie obowiązującą ustawą o podatkach i opłatach lokalnych $^{11}$, w której wartość jako podstawa opodatkowania została ograniczona jedynie do opodatkowania budowli ${ }^{12}$.

Analogiczny proces jak podatek od nieruchomości przeszedł podatek rolny. Wywodzi się on z ustawy o podatku gruntowym ${ }^{13}$, która została znowelizowana ustawą z dnia 15 listopada 1984 r. Wówczas wprowadzono innowacyjne jak na ówczesne czasy rozwiązanie, mianowicie wprowadzone zmiany spowodowały, iż podatek gruntowy przybrał postać podatku składającego się z dwóch części. Pierwsza z nich obejmowała obecny, lecz nieco zmodyfikowany podatek gruntowy, obliczany przy zastosowaniu progresywnych stawek odnoszonych do przychodu szacunkowego gospodarstwa rolnego ustalonego na podstawie

9 Ustawa z dnia 26 lutego 1982 r. o opodatkowaniu jednostek gospodarki uspołecznionej (Dz.U. Nr 7, poz. 55 ze zm.).

10 Ustawa z dnia 14 marca 1985 r. o podatkach i opłatach lokalnych (Dz.U. Nr 12 poz. 50 ze zm.).

11 Ustawa z dnia 12 stycznia 1991 r. o podatkach i opłatach lokalnych.

12 L. Etel, Opodatkowanie nieruchomości..., s. 29.

13 Ustawa z dnia 26 października 1971 r. o podatku gruntowym (Dz.U. Nr 27, poz. 254 ze zm.). 
norm szacunkowych przychodu z 1 ha użytków rolnych i leśnych z doliczeniem przychodu z działów specjalnych. Natomiast druga część obejmowała podatek obliczany na podstawie powierzchni użytków rolnych wyrażonych w hektarach fizycznych i powierzchni gruntów ornych wyrażonych w hektarach przeliczeniowych, przy zastosowaniu stawek kwotowych $^{14}$. W taki sposób z podatku typowo przychodowego podatek gruntowy przeistoczył się w podatek przychodowo-majątkowy.

Dwoisty charakter podatku rolnego utrzymywał się do 1 stycznia 1992 r., tj. do wejścia w życie ustawy o podatku dochodowym od osób fizycznych $^{15}$ i ustawy o podatku dochodowym od osób prawnych ${ }^{16}$, które objęły swoim zakresem dochody uzyskiwane z działów specjalnych produkcji rolnej. Wyłączenie działów specjalnych produkcji rolnej z opodatkowania podatkiem rolnym spowodowało, że stał się on podatkiem obciążającym jedynie grunty gospodarstwa rolnego, a tym samym podobnie jak podatek od nieruchomości nabrał charakteru świadczenia majątkowego. Podstawę opodatkowania dla tego podatku stanowi:

- dla gruntów spełniających normę obszarową dla gospodarstw rolnych - liczba hektarów przeliczeniowych ustalana na podstawie powierzchni, rodzajów i klas użytków rolnych wynikających z ewidencji gruntów i budynków oraz zaliczenia do okręgu podatkowego;

- dla pozostałych gruntów - liczba hektarów fizycznych wynikająca z ewidencji gruntów i budynków.

Natomiast obowiązek podatkowy z tego tytułu związany jest wyłącznie $\mathrm{z}$ władaniem gruntami ${ }^{17}$.

14 L. Etel, Opodatkowanie nieruchomości..., s. 39.

15 Ustawa z dnia 26 lipca 1991 r. o podatku dochodowym od osób fizycznych (tekst pierw. Dz.U. Nr 80, poz. 350 ze zm.).

16 Ustawa z dnia 15 lutego 1992 r. o podatku dochodowym od osób prawnych oraz zmianie niektórych ustaw regulujących zasady opodatkowania (Dz.U. Nr 21, poz. 86 ze zm.).

17 Ustawa z dnia 15 listopada 1984 o podatku rolnym (tekst jedn. Dz.U z 2013 r., poz. 1381 ze zm.). 


\section{Uwarunkowania oraz dotychczasowe wyniki prac nad reformą systemu opodatkowania nieruchomości}

Funkcjonujący obecnie w Polsce system opodatkowania nieruchomości jest ostatnim elementem składowym polskiego systemu podatkowego, którego konstrukcja pozostała niezmieniona od lat 70. ubiegłego wieku. Pomimo zasadniczych zmian ustrojowych i politycznych, które nastąpiły w Polsce po 1990 r., opodatkowanie nieruchomości bazuje w dalszym ciągu na modelu wywodzącym się z minionego ustroju.

Pierwsze prace nad reformą rozpoczęto już w 1990 r., jednakże z różnych względów ich zaniechano. Przede wszystkim zabrakło woli politycznej do poważnego i kompleksowego zmierzenia się z tym tematem ${ }^{18}$. Bariera polityczna nie jest jedyną, z jaką przyszło się zmierzyć reformie. Niewątpliwie znacznym utrudnieniem była - i jest nadal nieistniejąca, a z pewnością konieczna - pełna oraz wiarygodna baza ewidencyjna.

Wprawdzie trwają prace nad stworzeniem systemu katastralnego zgodnie z zaleceniami ekspertów Unii Europejskiej, który obejmował będzie trzy dopełniające się ogniwa, tj.:

- zmodernizowaną ewidencję gruntów i budynków - kataster nieruchomości;

- przeniesione do systemów informatycznych księgi wieczyste kataster prawny;

- $\quad$ nowoczesną ewidencję podatkową nieruchomości - kataster fiskalny ${ }^{19}$.

Jednak wyniki kontroli Zintegrowanego Systemu Katastralnego przeprowadzone w okresie 2000-2005 (I półrocze) przez Najwyższą Izbę Kontroli wskazują jednoznacznie, że wykonanie wszystkich prac

18 M. Mikiciuk, Podatek katastralny jako docelowy system opodatkowania nieruchomości w Polsce $w$ dobie kryzysu finansów publicznych, „Rzeczpospolita” z dn. 29.01.2013 r. [wyd. on-line], http://www.rp.pl/artykul/975225.html, (dostęp: 14.05.2014 r.).

19 T. Wołowiec, Reforma systemu opodatkowania nieruchomości w Polsce szansq pobudzenia rozwoju lokalnego i regionalnego samorzq̨dów terytorialnych, „Studia Regionalne i Lokalne” 2003, nr 4 [wyd. on-line], http://www.studreg.uw.edu.pl/ pdf/2003_4_wolowiec.pdf, (dostęp 14.05.2014 r.). 
i uruchomienie w pełni działającego systemu, zaplanowane pierwotnie na rok 2010, przewiduje się zrealizować dopiero w latach 2018-2019²0.

Zasadniczą jednak barierą w zmianie sposobu opodatkowania jest brak unormowań prawnych w tym zakresie. Wprawdzie w Narodowym Programie Przygotowania do Członkostwa w Unii Europejskiej ${ }^{21}$ w każdym roku wskazuje się na potrzebę pilnego przeprowadzenia prac legislacyjnych, mających na celu uchwalenie ustaw regulujących w sposób całościowy przyszły system opodatkowania nieruchomości, tj. ustawy o systemie katastralnym, nowelizacji ustawy prawo geodezyjne i kartograficzne, w zakresie zakładania i prowadzenia katastru nieruchomości, dostosowanie rozporządzenia w sprawie ewidencji gruntów i budynków do zasad zakładania i prowadzenia katastru nieruchomości.

Ustawy o systemie katastralnym nie udało się jeszcze przygotować, natomiast 6 maja 2014 r. do Sejmu wpłynął projekt ustawy o zmianie ustawy Prawo geodezyjne i kartograficzne.

Kolejną z barier wdrażanej reformy jest bez wątpienia bariera ekonomiczna. Według informacji NIK z marca 2006 r. prace wdrożeniowe Zintegrowanego Systemu Katastralnego tylko w latach 2000-2005 pochłonęły 150 mln zł. W 2006 roku szacowano, że pozostałe koszty związane z dokończeniem prac mogą wynieść około 770 mln zł. Przeważająca kwota środków przeznaczonych na ten cel pochodzi z bezzwrotnej pomocy zagranicznej realizowanej w ramach programu PHARE oraz z Banku Światowego. Ponadto uzupełnieniem omawianych kosztów będą koszty związane z przeprowadzeniem powszechnej taksacji nieruchomości, które szacunkowo miałyby wynieść ok. 2 mld zł.

Brak informacji na temat proponowanej reformy przekazywanej w sposób czytelny i jasny społeczeństwu jest następna przeszkodą, na którą napotyka reforma. Dotychczasowe działania władzy publicznej nie zmierzają do wyjaśnienia ani cech pozytywnych, ani tym bardziej nega-

20 Najwyższa Izba Kontroli, Informacja o wynikach kontroli Zintegrowanego Systemu Katastralnego w latach 2000-2005 (I pótrocze), marzec 2006, http://bs.net.pl/ upload/File/pdf2/px_2005183-kataster.pdf, (dostęp: 05.05.2014 r.).

21 Narodowy Program Przygotowania do Członkostwa $w$ Unii Europejskiej, http://www.polskawue.pl/Narodowy,Program,Przygotowania,do,Czlonkostwa,w,Unii, Europejskiej,126.html, (dostęp: 14.05.2014 r.). 
tywnych nowego rozwiązania. Dlatego pomimo licznych wskazanych powyżej barier legislacyjnych i ekonomicznych najtrudniejszą do pokonania może okazać się bariera społeczna. W opinii społecznej nałożenie nowych ciężarów podatkowych, i tak znacznie już obciążonego społeczeństwa, spotyka się ze znaczną krytyką. Toteż można odnieść wrażenie, że reformę próbuje się zachować w tajemnicy ${ }^{22}$.

Biorąc pod uwagę członkostwo Polski w Unii Europejskiej, należy wskazać, że podatki od nieruchomości jako daniny lokalne nie realizują w dostateczny sposób zasad zawartych w Europejskiej Karcie Samorządu Terytorialnego ${ }^{23}$, ratyfikowanej przez Polskę w 1993 r. Należy tu wymienić zawartą w art. 9 zasadę subsydiarności i adekwatności, zasadę autonomii podatkowej oraz zasady zróżnicowania i elastyczności systemów finansowania samorządów ${ }^{24}$.

Zwiększenie autonomii fiskalnej samorządów to $\mathrm{z}$ jednej strony szansa na inwestycje infrastrukturalne, stanowiące siłę napędową rozwoju lokalnego i regionalnego, a z drugiej możliwość pozyskiwania funduszy unijnych na inwestycje oraz łatwiejszego sięgania po kredyty.

Zreformowanie systemu opodatkowania nieruchomości w Polsce stanowi dużą szansę uzyskania przez samorządy lokalne stabilnych i wydajnych źródeł dochodów własnych, z których samorządy mogą finansować inwestycje infrastrukturalne, stanowiące podstawowe źródło aktywizacji lokalnej i regionalnej. Z tego powodu samorządy są zainteresowane wprowadzeniem reformy i bardzo wspierają tę ideę. Założeniem reformy nie jest spowodowanie znaczącego wzrostu obciążenia podatkowego społeczeństwa, a raczej rozszerzenie zakresu opodatkowania na znaczną „szarą strefę” podatników podatków od nieruchomości. Na podstawie danych z początku lat 90 . rozmiar szarej strefy w sferze opo-

22 P. Felis, System opodatkowania nieruchomości w Polsce, „Infos” 2012, nr 14, http://orka.sejm.gov.pl/WydBAS.nsf/0/E6E635EA3629F78FC1257A40003D871F/\$ file/Infos_128.pdf, (dostęp: 05. 05.2014r.); Najwyższa Izba Kontroli, Informacja o wynikach kontroli...

23 Europejska Karta Samorządu Terytorialnego sporządzona w Strasburgu dnia 15 października 1985 r. (Dz.U. z 1994 Nr 124, poz. 607 ze sprost.).

24 M. Mikiciuk, Podatek katastralny... [wyd. on-line]. 
datkowania nieruchomości wskazywany przez organy podatkowe gmin kształtował się na poziomie od 30 do $40 \%$ niepłaconych podatków ${ }^{25}$.

Podkreślenia wymaga również fakt, że przesłanki, którymi kierowano się, rozpoczynając prace nad reformą opodatkowania nieruchomości w Polsce, pomimo upływu czasu, nakładu pracy i środków nie straciły na swej aktualności.

Z założenia celami, które przyświecają reformie opodatkowania nieruchomości, są m.in.:

- uproszczenie systemu podatków lokalnych poprzez zastąpienie trzech istniejących obecnie podatków jednym podatkiem od nieruchomości;

- $\quad$ ustalenie jednej wartościowej podstawy opodatkowania, która wynikać powinna z katastru nieruchomości;

- nadanie katastrowi charakteru fiskalnego oraz powierzenie prowadzenia go samorządowym urzędom katastralnym;

- przekazanie części kompetencji w zakresie kształtowania stawek podatkowych, ulg i zwolnień organom samorządu terytorialnego;

- $\quad$ urealnienie obciążenia podatkowego gruntów rolnych i leśnych;

- $\quad$ wyrównanie poziomu opodatkowania poszczególnych nieruchomości;

- rozszerzenie cywilistycznego pojęcia nieruchomości o definicje wynikające $\mathrm{z}$ prawa budowlanego lub ustalenie pojęcia nieruchomości dla celów podatkowych;

- $\quad$ wprowadzenie szczelnej i odpowiadającej rzeczywistości ewidencji gruntów i budynków;

- $\quad$ ograniczenie unikania opodatkowania poprzez nieujawnienie istniejącej nieruchomości, a tym samym niezgłoszenie jej do opodatkowania lub też w przypadku gruntów urzeczywistnienie prawidłowej ich klasyfikacji, która jednoznacznie wyeliminowałaby ucieczkę podatników w preferencyjne opodatkowanie;

- $\quad$ zwiększenie dochodów własnych samorządu z tytułu opodatkowania nieruchomości przy jednoczesnym utrzymaniu obecnego poziomu

25 T. Wołowiec, Reforma systemu opodatkowania nieruchomości w Polsce... [wyd. on-line]. 
obciążenia podatkowego poprzez uszczelnienie „bazy opodatkowania” tym podatkiem;

- $\quad$ dostosowanie polskiego systemu opodatkowania nieruchomości do systemów obowiązujących w Unii Europejskiej ${ }^{26}$.

Sama istota opodatkowania ad valorem wydaje się być prostą oraz naturalną konsekwencją systemu podatkowego opartego na wartościach i wielkościach rynkowych. Z powodzeniem funkcjonuje ona w krajach o rozwiniętej gospodarce rynkowej, gdzie docenia się rolę takiego sposobu opodatkowania.

\section{Pojęcie i rodzaje katastru oraz cechy systemu katastralnego} jako szeroko rozumianej ewidencji

Rozważania na temat funkcjonowania katastru należy rozpocząć od wyjaśnienia samego pojęcia. Kataster wywodzi się od łacińskiego słowa capitastrum, co oznaczało rejestr podatku pogłównego, a zostało utworzone na podstawie greckiego terminu katastikhon, który oznaczał rejestr (w znaczeniu dosłownym „linia po linii”) ${ }^{27}$. Słownikowe wyjaśnienie słowa „kataster” oznacza urzędowy spis, rejestr obiektów (gruntów, nieruchomości) z oszacowaniem ich wartości i wykazem dochodów, służący głównie do celów podatkowych ${ }^{28}$. Natomiast według dekretu o katastrze gruntowym i budynkowym z 1947 r. ${ }^{29}$ „kataster to oparty na mapie spis i opis gruntów i budynków, mogących być oddzielnym przedmiotem własności”.

Zgodnie z art. 2 dekretu kataster gruntowy i budynkowy służył za podstawę:

26 L. Etel, R. Dowgier, Podatki i opłaty..., s. 24-29.

27 Instytut Geodezji i Kartografii, http://www.igik.edu.pl/pl/a/Kataster-def, (dostęp: 04.05.2014 r.).

28 W. Kopaliński, Słownik wyrazów obcych i zwrotów obcojęzycznych, Warszawa 1999, s. 257.

29 Dekret z dnia 24 września 1947 r. o katastrze gruntowym i budynkowym (Dz.U. Nr 61, poz. 344). 
- opisów i planów dla oznaczenia nieruchomości przy zakładaniu i prowadzeniu ksiąg wieczystych;

- $\quad$ zakładania i prowadzenia ksiąg górniczych, wodnych i innych;

- $\quad$ wymiaru danin, podatków i innych świadczeń publicznych;

- dostarczania danych w zakresie objętym katastrem dla różnych dziedzin techniki oraz życia społecznego i gospodarczego.

Współcześnie przez kataster nieruchomości należy rozumieć opartą na mapie urzędową ewidencję gruntów i budynków oraz innych obiektów stanowiących przedmiot opodatkowania, a także źródło informacji o podmiotach katastralnych (osobach fizycznych i prawnych będących właścicielami lub posiadaczami nieruchomości).

Kataster jest systemem informacyjnym funkcjonującym w sposób ciągły, co oznacza, że nie stanowi on jednorazowego spisu nieruchomości. Posiada charakter urzędowy, co oznacza, że działa na podstawie ustaw i rozporządzeń oraz jest prowadzony i nadzorowany przez organy administracji państwowej lub samorządowej. Kataster jest systemem informacji publicznej, dostępnym dla wszystkich zainteresowanych, którzy mogą wykorzystywać zawarte w nim dane dla własnych potrzeb $^{30}$. Istotą katastru jest pełna zgodność danych zawartych w ewidencji gruntów i budynków z danymi zawartymi w księdze wieczystej.

Ze względu na zakres gromadzonych informacji oraz celów, które podlegają jego realizacji, wyróżnia się;

- $\quad$ kataster fizyczny (ewidencja gruntów i budynków);

- $\quad$ kataster prawny (księgi wieczyste);

- $\quad$ kataster fiskalny (ewidencja podmiotów i przedmiotów opodatkowania).

Kataster fizyczny jest zbiorem informacji o terenie inwentaryzującym nieruchomości położone na danym obszarze pod względem wyznaczenia granic i ich szczegółowego opisu. Zawiera plany, mapy, opisy i dane określające przeznaczenie oraz sposób użytkowania nieruchomości ${ }^{31}$.

30 K. Wójtowicz, System opodatkowania nieruchomości w Polsce, Lublin 2007, s.15-16.

31 M. Wróblewska, Kataster nieruchomości, [w:] J. Głuchowski, A. Pomorska, J. Szołno-Koguc (red.), Główne wyzwania i problemy systemu finansów publicznych, Lublin 2009, s.652. 
Zauważyć należy, że powyższe informacje dotychczas zawarte są w ewidencji gruntów i budynków. Ustawodawca definiując w art. 2 pkt. 8 ustawy „ewidencję gruntów i budynków” jako „jednolity dla kraju, systematycznie aktualizowany zbiór informacji o gruntach, budynkach i lokalach, ich właścicielach oraz o innych osobach fizycznych lub prawnych władających tymi gruntami, budynkami i lokalami”32, zamiennie posługuje się terminem „kataster nieruchomości”, wskazując, że przez to pojęcie do czasu przekształcenia rozumie się ewidencję ${ }^{33}$.

W ewidencji gruntów i budynków powinno wykazywać się wartość nieruchomości. Stanowi o tym art. 20 pkt. 2 ust. 4 ustawy prawo geodezyjne i kartograficzne. Do tej pory jednak informacje na temat wartości nieruchomości nie znajdują odbicia w prowadzonej ewidencji. Ma to zmienić wprowadzenie katastru nieruchomości. Do informacji zawartych w katastrze zostaną dołączone informacje o wartości katastralnej każdej nieruchomości, która stanowić będzie podstawę opodatkowania ${ }^{34}$.

Kataster prawny jest ewidencją, w której odzwierciedlony zostaje stan prawny nieruchomości. Głównym jego zadaniem jest rejestracja właścicieli oraz praw do danej nieruchomości. Zawiera głównie dane o prawie własności i innych prawach oraz obciążeniach związanych z nieruchomością, np. użytkowaniu, użytkowaniu wieczystym, służebności, dzierżawie, najmie, użyczeniu czy zarządzie. Obecnie tę funkcję spełniają księgi wieczyste. Pomiędzy katastrem prawnym a katastrem fizycznym istnieje ścisła relacja, albowiem dane zawarte w ewidencji gruntów i budynków są podstawą oznaczania nieruchomości w księgach wieczystych. Wdrożenie katastru prawnego powinno zostać poprzedzone uporządkowaniem stosunków prawnych każdej nieruchomości oraz ustaleniem ich granic poprzez wykonanie precyzyjnych pomiarów geodezyjnych. Wykonanie obydwu tych czynności wiąże się z poniesieniem dużych nakładów finansowych i jest zabiegiem czasochłonnym. Prowadzenie ewidencji podatkowej na podstawie danych uzyskiwanych

\footnotetext{
32 Ustawa z dnia 17 maja 1989 r. Prawo geodezyjne i kartograficzne (tekst jedn. Dz.U. z 2010 r. Nr 193 poz. 1287 ze zm.).

33 Art. 53a ustawy.

34 M. Wróblewska, Kataster nieruchomości..., s. 652-654.
} 
z ksiąg wieczystych ukazuje istnienie ścisłego związku pomiędzy katastrem podatkowym i prawnym.

Z kolei kataster fiskalny charakteryzuje się ścisłym związkiem z systemem podatkowym państwa, któremu służy. Celem katastru fiskalnego jest przede wszystkim ustalenie wartości nieruchomości i podmiotu zobowiązanego do zapłaty podatku. Zostają więc w nim odzwierciedlone dane niezbędne do wymierzania podatków obciążających nieruchomości takie jak: dane podatnika, wartość nieruchomości i dochody uzyskiwane z nieruchomości.

Kataster fiskalny tworzony jest tylko dla potrzeb opodatkowania nieruchomości, co oznacza, że dane w nim zawarte nie mogą być wykorzystywane w innych celach ${ }^{35}$. Namiastką budowy katastru fiskalnego w Polsce jest prowadzona od 1 stycznia 2005 r. ewidencja podatkowa nieruchomości. Na podstawie danych w niej zawartych zostanie ustalona wartość katastralna, która ma być wartością ustaloną w procesie powszechnej taksacji nieruchomości. Kwestia wyznaczania wartości katastralnej została uregulowana w rozdziale 2 (art. 160 do 173) ustawy o gospodarce nieruchomościami ${ }^{36}$. Wynika z niej, że „wartość katastralna będzie ustalana na podstawie oszacowania nieruchomości reprezentatywnych dla poszczególnych rodzajów nieruchomości na terenie danej gminy. Przy czym powinna ona uwzględniać różnice, jakie występują pomiędzy poszczególnymi nieruchomościami oraz cechować się zbliżeniem do wartości rynkowej możliwej do osiągnięcia podczas masowej wyceny”. Natomiast zgodnie z art. 161 cytowanej ustawy wyznaczenie wartości katastralnej zostanie poprzedzone powszechną taksacją nieruchomości przeprowadzoną przez organy prowadzące kataster. Zauważyć należy, że unormowanie sposobu przeprowadzenia powszechnej taksacji nieruchomości zostało określone w jeszcze innym akcie prawnym, tj. Rozporządzeniu Rady Ministrów z dnia 19 października 2005 r. ${ }^{37}$

35 L. Etel, Reforma opodatkowania ..., s. 210.

36 Ustawa z dnia 21 sierpnia 1997 r. o gospodarce nieruchomościami (tekst jedn. Dz.U. z 2014 r., poz. 518 ze zm.).

37 Rozporządzenie Rady Ministrów z dnia 29 czerwca 2005 r. w sprawie powszechnej taksacji nieruchomości (Dz.U. Nr 131, poz. 1092). 
Komisja Europejska w dokumencie „Partnerstwo dla Członkostwa z Polską z 1998 r.”38 wskazała na konieczność konsolidacji rynku nieruchomości oraz potrzebę opracowywania katastru nieruchomości, uznając te działania za priorytetowe cele dostosowawcze, niezbędne do spełnienia kryterium gospodarczego członkostwa Polski w Unii Europejskiej.

Opracowany w Narodowym Programie Przygotowania do Członkostwa w Unii Europejskiej z 1998 r. priorytet $10.2^{39}$ wskazywał na konieczność zreformowania systemu opodatkowania i ewidencjonowania nieruchomości w Polsce. Ze względu na znaczenie oraz zakres reformy związanej z utworzeniem Systemu Katastralnego powołany został przez Prezesa Rady Ministrów Zarządzeniem Nr 13 z dnia 18 marca 1999 r. specjalny Zespół do Spraw Opracowania i Koordynacji Rządowego Programu Rozwoju Systemu Katastralnego. W skład tego zespołu weszli przedstawiciele z Ministerstwa Spraw Wewnętrznych i Administracji, Głównego Urzędu Geodezji i Kartografii, Ministerstwa Finansów oraz Ministerstwa Sprawiedliwości. Zadaniem zespołu było opracowanie „Rządowego Programu Rozwoju Systemu Katastralnego”, który w swoim założeniu powinien doprowadzić do integracji trzech składników systemu, tj. katastru fizycznego, katastru prawnego i katastru fiskalnego. W priorytecie 30.9 Narodowego Programu Przygotowania do Członkostwa w Unii Europejskiej w roku 2000 oraz w priorytecie $30.8 \mathrm{z}$ roku 2001 tego samego programu, zostały określone zadania dotyczące przekształcenia ewidencji gruntów i budynków w kataster nieruchomości. Średniookresowym celem priorytetu 30.9 z 2000 r., określonym w zadaniu drugim, było utworzenie Zintegrowanego Systemu Katastralnego. Natomiast modernizacja dotychczasowej ewidencji gruntów przeprowadzona głównie poprzez jej obligatoryjną informatyzację i zakładanie ewidencji budynków i lokali stanowiących odrębny przedmiot własności, zostało w tym priorytecie określone jako zadanie pierwszorzędne.

38 Partnerstwo dla Członkostwa z Polskq 1998 r., Centrum Informacji Europejskiej Urząd Komitetu Integracji Europejskiej, http://www.cie.gov.pl/HLP/files.nsf/0/651 AB9E734505779C1256E7B0047DCA4/\$file/APpl.pdf, (dostęp: 05.05.2014 r.).

39 Narodowy Program Przygotowania do Członkostwa w Unii Europejskiej..., [wyd. on-line]. 
Celem obydwu tych działań jest stworzenie bazy danych o nieruchomościach będącej źródłem rzetelnej i aktualnej informacji o wartości i o właścicielach gruntów, budynków i lokali oraz powiązania tej bazy z księgami wieczystymi i ewidencją podatkową jako komponentami Systemu Katastralnego.

Założone w omawianym programie cele pośrednie dotyczą:

- $\quad$ opracowania i uchwalenia ustawy o Systemie Katastralnym, w której określone zostaną m.in. zasady współdziałania trzech komponentów Systemu Katastralnego oraz ich powiązania z innymi rejestrami i ewidencjami publicznymi;

- nowelizacja ustawy Prawo geodezyjne i kartograficzne w zakresie zakładania i prowadzenia katastru nieruchomości jako komponentu Systemu Katastralnego;

- dostosowania rozporządzenia w sprawie ewidencji gruntów i budynków do zasad zakładania i prowadzenia katastru nieruchomości.

Prace związane z budową tego systemu zostały tylko częściowo zrealizowane w 2000 r., a priorytet 30.9 podlegał dalszemu wdrażaniu w Narodowym Programie Przygotowania do Członkostwa (NPPC) w roku następnym. W roku 2001 w priorytecie 30.8 NPPC określono, że budowa Zintegrowanego Systemu Katastralnego będzie polegała przede wszystkim na modernizacji i uzupełnieniu istniejących systemów oraz na stworzeniu sprawnej wymiany informacji między nimi. Zadanie to powierzono Zespołowi do Spraw Opracowania i Koordynacji Rządowego Programu Rozwoju Systemu Katastralnego. Zespół ten opracował podstawowe założenia do Rządowego Programu Rozwoju Systemu Katastralnego, na który mają składać się trzy podsystemy: księgi wieczyste (kataster prawny), ewidencja gruntów i budynków (kataster nieruchomości) oraz ewidencja podmiotów i przedmiotów opodatkowaniaewidencja podatkowa (kataster fiskalny). Stworzony system katastralny będzie również współdziałał z innymi rejestrami i ewidencjami publicznymi takimi jak np. ze statystyką publiczną.

Stworzenie zinformatyzowanego systemu ksiąg wieczystych jako jednego z elementów usprawniania polskiego sądownictwa przedstawiono w priorytecie 30.10 NPPC. Na chwilę obecną system ten został 
przygotowany i wdrożony w całości. W roku 2001 podobnie jak w roku poprzednim celem pośrednim omawianego programu było opracowanie ustawy o Systemie Katastralnym przez Zespół do Spraw Opracowania i Koordynacji Rządowego Programu Rozwoju Systemu Katastralnego. Niestety. celu tego nie udało się osiągnąć do dnia dzisiejszego.

Natomiast drugie z zadań określonych w tym programie dotyczy zmiany sposobu opodatkowania nieruchomości, która to zmiana ma polegać na zastąpieniu kryterium powierzchni przy ustalaniu podstawy opodatkowania wartością nieruchomości (formuła ad valorem) oraz pełnemu zintegrowaniu ewidencji podmiotów i przedmiotów opodatkowania (rejestru fiskalnego) z rejestrem prawnym (księgami wieczystymi) i rejestrem gruntów i budynków (katastrem fizycznym) w ramach jednego zintegrowanego systemu katastralnego.

Jako cel pośredni przy realizacji tego programu przyjmuje się zwiększenie dochodów jednostek samorządu terytorialnego z tytułu podatków od nieruchomości oraz poprawę działania administracji samorządowej w zakresie ściągalności podatków lokalnych, których realizacja zostanie uzyskana przy poniesieniu minimalnych nakładów.

Zrealizowanie tego celu zamierza się uzyskać poprzez:

- $\quad$ modernizację i uzupełnienie ewidencji podatkowej prowadzonej przez samorządy, w tym zapewnienie informatycznego połączenia z ewidencją gruntów i budynków (kataster nieruchomości);

- $\quad$ uproszczenie wymiaru i poboru podatków lokalnych;

- $\quad$ poprawę efektywności działania struktur samorządowej administracji podatkowej;

- wprowadzenie nowych zasad opodatkowania nieruchomości w odniesieniu do ich wartości z wykorzystaniem wyników prac nad powszechną taksacją nieruchomości.

Rozwiązania polskie odbiegają od przyjętych w poszczególnych państwach członkowskich Unii Europejskiej w zakresie określania przedmiotu, podstawy i stawek opodatkowania podatkami lokalnymi. Wprawdzie brak odpowiednich regulacji prawa wspólnotowego w tym zakresie i poszczególne państwa mają prawo do stanowienia o obowiązującym modelu opodatkowania nieruchomości. Należy jednak zauwa- 
żyć, że opodatkowanie nieruchomości w formule ad valorem jest powszechnie przyjętym standardem w państwach Unii Europejskiej.

\section{Podsumowanie}

Mając na względzie usprawnienie systemu finansowania jednostek samorządu terytorialnego, wprowadzenie nowych regulacji wydaje się niezbędne, gdyż podatek w formule ad valorem zdaje się być stabilnym i wydajnym źródłem dochodów własnych gmin. Jednoczesne przeprowadzenie zmian we wszystkich modułach zakładanego systemu jest nierealne co najmniej ze względu na wysokie koszty wdrożenia i z uwagi na długi proces legislacyjny umożliwiający wprowadzenie zakładanych zmian. Dlatego zdecydowano się na rozłożenie wprowadzania zmian na etapy.

Stworzenie systemu wiarygodnej i pełnej ewidencji nieruchomości (nowoczesnego systemu katastralnego) jest podstawową przesłanką dla tworzonego w Polsce Zintegrowanego Systemu Informacji o Nieruchomościach, w którym dokonywać się będzie automatyczna wymiany informacji pomiędzy trzema omawianymi wcześniej komponentami systemu ${ }^{40}$.

Nowoczesny system katastralny (ZSIN) będzie współdziałał również z innymi rejestrami i ewidencjami publicznymi takimi jak: ewidencją gospodarstw rolnych (IACS), ewidencją ludności (PESEL), ewidencją podmiotów gospodarczych (REGON).

Jak wskazuje się w literaturze przedmiotu, doświadczenia innych krajów zdobyte podczas tworzenia i funkcjonowania systemów katastralnych pozwalają na określenie kilku cech charakterystycznych oddających istotę takiego sytemu: kataster jest powszechnie stosowaną ewidencją nieruchomości, która jest wykorzystywana przy ustalaniu podatków nawet wtedy, gdy nie jest jej zasadniczym celem (kataster prawny), dane zawarte w ewidencjach katastralnych stanowią podstawę do określenia podatnika, przedmiotu opodatkowania, podstawy wymiaru, co

40 P. Felis, System opodatkowania nieruchomości w Polsce..., [wyd. on-line]. 
zwiększa efektywność opodatkowania i uniemożliwia uchylanie się od płacenia podatków od nieruchomości, podstawą opodatkowania nieruchomości jest ich wartość rzeczywista (rynkowa) lub tzw. czynszowa ustalana przez rzeczoznawców według określonych ustawowo zasad lub wyjątkowo wskazana przez samego podatnika, obowiązkiem podatkowym objęte są wszystkie rodzaje nieruchomości, podatnikiem jest właściciel nieruchomości, a podatki te stanowią dochód jednostek samorządu terytorialnego.

\section{Bibliografia:}

Etel L., (red.) Europejskie systemy opodatkowania nieruchomości, Wydawnictwo Sejmowe, Warszawa 2003.

Etel L., Opodatkowanie nieruchomości problemy praktyczne, Wydawnictwo Temida 2, Białystok 2001.

Etel L., Podatki i opłaty lokalne - czas na zmiany, Wydawnictwo Temida 2, Białystok 2013.

Etel L., Reforma opodatkowania nieruchomości w Polsce, Wydawnictwo Temida 2, Białystok 1998.

Felis P., System opodatkowania nieruchomości w Polsce, „Infos” 2012, nr 14 [wyd. on-line].

Kopaliński W., Słownik wyrazów obcych i zwrotów obcojęzycznych, Wydanie XXV, PWN, Warszawa 1999.

Mastalski R., Prawo podatkowe II, część szczegółowa, Wydawnictwo C.H.BECK, Warszawa 1996.

Mikiciuk M., Podatek katastralny, jako docelowy system opodatkowania nieruchomości w Polsce w dobie kryzysu finansów publicznych, „Rzeczpospolita” $\mathrm{z}$ dn. 29.01.2013 r.

Najwyższa Izba Kontroli, Informacja o wynikach kontroli Zintegrowanego Systemu Katastralnego w latach 2000-2005 (I pótrocze), marzec 2006 [on-line].

Partnerstwo dla Członkostwa z Polskq 1998 r., Centrum Informacji Europejskiej Urząd Komitetu Integracji Europejskiej, Warszawa 1998.

Wołowiec T., Reforma systemu opodatkowania nieruchomości w Polsce szansq pobudzenia rozwoju lokalnego i regionalnego samorzqdów terytorialnych, „Studia Regionalne i Lokalne” 2003, nr 4 [wyd. on-line]. 
Kataster jako warunek reformy systemu opodatkowania...

Wójtowicz K., System opodatkowania nieruchomości w Polsce, Wydawnictwo UMCS, Lublin 2007.

Wróblewska M., Kataster nieruchomości, [w:] J. Głuchowski, A. Pomorska, J. Szołno-Koguc (red.), Główne wyzwania i problemy systemu finansów publicznych, Wydawnictwo KUL, Lublin 2009. 